\title{
Magyar vállalatok külföldi tőkeberuházásai: helyzetkép és a továbblépés lehetőségei
}

Outward Foreign Direct Investments of Hungarian Companies: Their Situation and the Opportunities for Further Progress

\section{Endrődi-Kovács Viktória és Goreczky Péter https://doi.org/10.47707/Kulugyi_Szemle.2020.3.07}

Összefoglaló: A közelmúltban a külgazdasági törekvések között egyre nagyobb hangsúlyt kaptak a hazai vállalatok tőkekihelyezései. A jelen tanulmány célja annak a vizsgálata, hogy hol tart Magyarország a tőkekihelyezővé válás folyamatában, és milyen kilátásai vannak az új külgazdasági prioritás megvalósítására. A tanulmány elkészítése során a módszertani eszközök közül a szekunder adatok elemzésével, illetve tőkekihelyező magyar vállalatokkal készített interjúkon alapuló esettanulmányokkal éltünk. A fő konklúziónk, hogy hazánk a beruházási fejlődési modell 3. szakaszának az elején tart, ami azt jelenti, hogy az állami támogatásoknak fontos szerepük van a továbblépésben. A hazai vállalatok kifelé irányuló közvetlen tőkebefektetéseinek (OFDI) a motivációi sokrétúek, a legnagyobb akadályukat viszont jellemzően az információ, illetve a helyismeret hiánya jelenti. Az előrelépéshez az állam elsődlegesen azzal tud hozzájárulni, ha támogató környezetet teremt a magyar cégek nemzetköziesedéséhez. A tanulmány fó értéke az elvégzett primer kutatás, illetve a kiválasztott téma, amelyről eddig csak kevés hazai elemzés született.

Kulcsszavak: beruházási fejlődési modell, magyar tőkekihelyezés, magyar OFDI, állami támogatások

\begin{abstract}
Recently the outward foreign direct investments (OFDI) of Hungarian companies have received a growing attention within the external economic strategy. The aim of this study is to evaluate Hungary's outward investment position and the prospects of realising this new priority in external economic governance. Applied methodological tools include the analysis of secondary data and case studies based on interviews with Hungarian outward investor companies. The main conclusions are that Hungary is at the beginning of the third phase in the investment development path model, where the role of state support should be important. The motivations of Hungarian companies to invest in abroad are diverse while the biggest obstacles are the lack of information and local knowledge. In order to make progress the state can contribute with ensuring the supporting environment for the internationalisation of Hungarian firms. Main values of this study are the conducted primary research and the topic itself, about which only a few domestic studies have been published so far.
\end{abstract}

Keywords: investment development path model, Hungarian capital investment, Hungarian OFDI, state support 


\section{Külügyi Szemle}

\section{Bevezetés}

A magyar vállalatok külföldi tőkeberuházásai némileg váratlanul kerültek napirendre a gazdasági témákkal foglalkozó sajtóban. A Magyarországra érkező beruházásokról szóló híradások megszokottak voltak, összhangban a kormány azon célkitúzésével, hogy hazánk először a régió gyártási, majd kutatás-fejlesztési központjává váljon. Orbán Viktor miniszterelnök 2019. február 27-én, a Magyar Kereskedelmi és Iparkamara gazdasági évnyitó rendezvényén mondott beszédében azonban az egyik legfontosabb feladatként már egy kifektetési stratégia elkészítését nevezte meg. A miniszterelnök azt is hangsúlyozta, hogy forrásokat kell teremteni azon magyar vállalkozások számára, amelyek hajlandóak külföldön beruházásokat végrehajtani. (Miniszterelnöki Kabinetiroda, 2019).

A John Dunning által a beruházási fejlődési pályáról (investment development path, IDP) készített modellje szerint egy ország a fejődésével (az egy főre jutó bruttó hazai termék növekedésével) párhuzamosan válik tőkebefogadóból tőkekibocsátó állammá. A kifelé irányuló közvetlen külföldi beruházásai pedig segítik a tôkeforrásai diverzifıkációját, valamint általában pozitív hatással bírnak a gazdasági növekedésére. A Magyarországra érkező közvetlen külföldi beruházásokról, azok motivációiról, gazdasági hatásairól már több hazai tanulmány is született (a teljesség igénye nélkül: Gál, 2019; Bisztray, 2016; Gál, Sass és Juhász, 2016; Balatoni és Pitz, 2012), azonban a magyar közvetlen külföldi beruházásokról viszonylag kevés szakirodalom létezik (ilyen például Antalóczy, Éltető és Sass, 2014; Sass, 2016a). Így a jelen tanulmány célja, hogy megvizsgálja, hol tart Magyarország a tőkekihelyezővé válás folyamatában, és milyen kilátásai vannak az újonnan meghirdetett külgazdasági prioritás megvalósítására.

A tanulmány elkészítése során alapvetôen négy kérdésre összpontosítottunk:

- Hol tart az ország az elméleti modellek alapján a tőkekihelyezővé válás folyamatában?

- Milyen következtetések vonhatók le a regionális és az ágazati statisztikákból?

- Milyen fontos szempontok azonosíthatók a vállalati esettanulmányok alapján?

- Hogyan múködik az állami támogatás a gyakorlatban?

A tanulmány alapvetően a fenti kérdések mentén épül fel, és négy fejezetre osztható. A módszertani ismertető utáni első részben a kifelé irányuló közvetlen külföldi tőkeberuházások (outward foreign direct investment, OFDI) elméleti hátteréből kiemeljük és bemutatjuk az OFDI-projektek típusait (motiváció alapján), valamint a Dunning-féle beruházási fejlődési pálya modelljét. A második fejezet azt vizsgálja, hogy az elérhető statisztikai adatok alapján hazánk az IDP-modell melyik szakaszában jár, azaz reális-e, hogy Magyarország a közeljövőben tőkekibocsátó állam legyen. A harmadik fejezet öt kiválasztott magyar vállalat külföldi beruházásait elemzi, a levonható általános 
következtetésekre összpontosítva. Az utolsó rész pedig arról szól, hogy a magyar állam jelenleg milyen eszközökkel támogatja a vállalatok OFDI-projektjeit, és merre kellene továbbhaladnia.

\section{Módszertan}

Tanulmányunk elkészítése során mind kvantitatív, mind kvalitatív elemzési eszközöket felhasználtunk.

John Dunning nemzetközi beruházási modellje mentén adatelemzéssel állapítottuk meg, hogy Magyarország tőkekihelyezés szempontjából hányadik fázisban áll, és merre kellene továbbfejlődnie. Az adatelemzés és a nettó tőkekihelyezési pozíció elemzése során figyelembe vettük, illetve igyekeztük kiküszöbölni a modell korlátjait (lásd: a következő fejezet). Makroszintű, szekunder - a Magyar Nemzeti Bank által gyűjtött adatokat használtunk fel, mivel primer adatgyűjtésre a téma jellegéből adódóan nem volt lehetőségünk. A közvetlen külföldi beruházásra (foreign direct investment, FDI) vonatkozó adatoknál szintén figyelembe vettük azok lehetséges korlátjait, ezért ott az eszköz-átcsoportosítás kiküszöbölése érdekében állományi adatokkal dolgoztunk, az átfolyó tőke hatásainak a kiszűréséért pedig nem speciális célú vállalatok adatait vizsgáltuk. Ugyanakkor érdemes megemlíteni, hogy az FDI-statisztikák összes lehetséges buktatóját lehetetlen kikerülni (lásd: Sass és Vlčková, 2020). Az adatok rendelkezésre állásának figyelembevételével a vizsgált időszakot 1995 és 2018 között határoztuk meg.

A vállalati esettanulmányok elkészítéséhez - részben primer kutatásként - interjúkat készítettünk, amelyeket az egyes beruházásokról egyéb forrásokból származó, elsősorban hírportálokon elérhető információkkal egészítettük ki. Az interjúk elkészítésénél a lehetséges kutatói hibák minimalizálása érdekében, illetve a hatás és etika szempontjából Almadi Sejla (2018, 8. o.) előirányzásait követtük.

Az esettanulmányokban szereplő öt magyar vállalat kiválasztásánál arra törekedtünk, hogy a legismertebb külföldön befektető hazai nagyvállalatok mellett kisebb cégek projektjei is helyet kapjanak. Mivel valamennyien termelő beruházásokat hajtottak végre - s azok összetettebb projektek, mint akár a szolgáltatóipari beruházások, akár a vállalati felvásárlások -, ezért a velük készült interjúkból és a beruházásaikról szóló hírekből összeállított esettanulmányok megfelelőek a többféle szempont szerinti elemzésre. A birtokunkba jutott információk közül terjedelmi korlátok miatt csak a legfontosabbakat szerepeltetjük a tanulmányban, három téma szerinti csoportosításban:

- $\quad$ a külföldön végrehajtott beruházás a vállalati stratégia tükrében;

- a beruházási helyszín kiválasztásának szempontjai és az implementáció;

- tapasztalatok és kihívások. 


\section{Külügyi Szemle}

Természetesen a minta - az alacsony elemszámból adódóan - nem tekinthető reprezentatívnak, ugyanakkor fontos információkkal, tanulságokkal szolgálhat a magyar szakirodalom számára arról, hogy mely tényezők teszik lehetóvé a magyar vállalatok sikeres külföldi terjeszkedését, és azokat a magyar állam hogyan támogatja, illetve hogyan kellene támogatnia annak érdekében, hogy Magyarország tőkekifektető állammá váljon.

A jelenlegi állami támogatási gyakorlat jobb megértése és feltérképezése céljával interjúkat készítettünk az EXIM, illetve a Magyar Exportfejlesztési Ügynökség (HEPA) képviselőivel is. Az elóbbi esetében az alkalmazott támogatási eszközökkel kapcsolatos kérdéseket tettünk fel, az utóbbinál készített interjú során pedig kifejezetten a NyugatBalkán Beruházási Támogatás programnak a részleteire voltunk kíváncsiak.

\section{A tőkekihelyezés egyes elméleti kérdései}

A tôkekihelyezés célja, előnyei és korlátjai

A közvetlen külföldi beruházás az a pénzügyi folyamat, amely révén egy vállalat tartós befolyást szerez egy másik országban lévő cég felett (UNCTAD, 2007, 245. o.). A tókekihelyezés számos előnnyel bírhat, többek között a vállalati növekedés, a profitabilitás elősegítése vagy éppen a visszaesés megállítása, a piaci kockázat csökkentése és diverzifikálása, olcsóbb erőforrásokhoz való hozzáférés, adózási előnyök vagy javuló minőség és hatékonyság (Franco, Rentocchini és Marzetti, 2008, 3-4. o.). Azonban hátrányai is lehetnek: megnövekedett piaci verseny, árfolyamkockázat, a nagyobb fizikai/ kulturális távolság miatt növekvő reakcióidő, partnerkockázat, kulturális különbségek vagy a beruházás elsüllyedt költségei (Szerb, Márkus és Csapi, 2015), amelyek mind a megtérülést fenyegetik. A külföldön történő beruházások több tényezőtől is függenek, többek között a vállalat méretétől, céljaitól, a rendelkezésére álló erőforrásoktól, a nyelv- és helyismerettől, illetve a kapott állami támogatásoktól. Ezek mentén a tókekihelyezés korlátja többféle lehet: forrás- és kapacitáshiány; a gazdasági és politikai, valamint egyéb nem kereskedelmi kockázattól való félelem (például kisajátítás, háború, a külföldi valuta konvertibilitásának a megszúnése, állami kötelezettségszegés) (Gorynia, Nowak, Trapczyński és Wolniak, 2015, 241. o.), továbbá a célországgal kapcsolatos információk, partnerek hiánya, a nyelv és a kultúra nem elégséges ismerete.

A szakirodalomban általánosan elfogadott FDI-típusok, motivációk a vállalati stratégia szempontjából a következők: 1. erőforrás-kereső, 2. piackereső, 3. hatékonyságkereső, valamint 4. stratégiaielőny-kereső. Az erőforrás-kereső FDI esetében a vállalat célja, hogy valamilyen erőforráshoz - nyersanyagokhoz, emberi erőforráshoz vagy tókéhez - jusson. A piackereső FDI esetén a meghatározó tényező a piac mérete, annak növekedési kilátásai, az egy főre jutó jövedelem, a fogyasztói preferenciák, a regionális 
s a nemzetközi piacok elérhetősége. A hatékonyságkereső FDI célja, hogy a vállalat egésze szintjén értelmezett költségeket csökkentse. Az ilyen típusú befektetés meghatározója a munkaerő, a tőkeforrás, a természeti erőforrások, illetve a szállítás és az infrastruktúra-használat költsége. Ez a fajta FDI az erőforrások globális eloszlásának a hatékonyságát növeli. A stratégiaielőny-kereső FDI egyre nagyobb szerepet tölt be a vállalatok életében; célja, hogy olyan materiális és immateriális eszközökhöz férjen hozzá a vállalat, amelyek révén előnyre tehet szert a versenytársaival szemben (Dunning, 1997, 154-155. o.). Napjainkban egyszerre akár több stratégiai motiváció is megjelenik egy-egy közvetlen külföldi befektetés kapcsán.

\section{A beruházási fejlődési modell}

John H. Dunning 1981-ben hozta létre a beruházási fejlődési modelljét, amelyet szerzőtársával, Rajneesh Narulával fejlesztett tovább.

Az elméletet Dunning eklektikus paradigmájának az alkalmazásaként tartják számon, és a transznacionális vállalatok nemzetköziesedésének makroszintú kiterjesztéseként értelmezhető. Az IDP-modell egy dinamikus megközelítés, amely egy ország közvetlen külföldi befektetéseinek a nettó pozícióját, azaz a kifelé, illetve befelé irányuló FDI közötti különbségét (net outward investment position, NOIP), valamint annak a különféle fejlettségi szintjei közötti szisztematikus kapcsolatot vizsgálja (Ahn és Ngoc, 2016, 3. o.). Dunning és Narula az elméletben öt lépcsőfokát különbözteti meg annak a folyamatnak, ahogyan egy ország a fejlődésével párhuzamosan a közvetlen külföldi beruházások bevonzójából tőkekihelyezővé válik, ami révén még több FDI érkezik hozzá, s végül a két folyamat kiegyenlítődik (lásd 1. ábra).

1. ábra'

A beruházási fejlődési pálya mintája

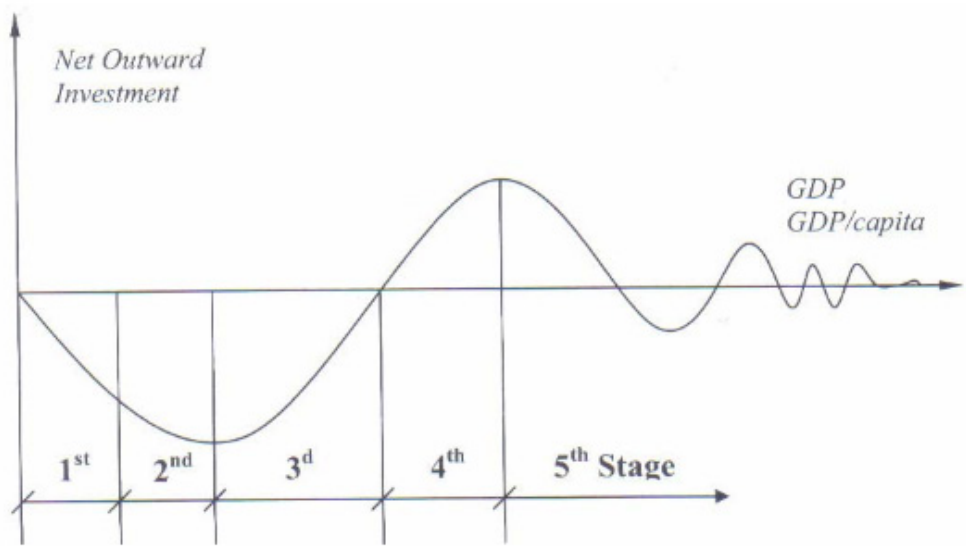

1 Forrás: Dunning és Narula, 2003, 2. o. 


\section{Külügyi Szemle}

Az első szakaszban egy adott ország elsősorban a természeti erőforrásoktól függ, és valószínúleg azok vonzzák be a közvetlen külföldi befektetéseket a munkaerő-igényes vagy az elsődleges terméket elóálító ágazatokba. Ebben a szakaszban az országok általában kevésbé fejlett intézményekkel rendelkeznek, és nem jellemző a tôkekivitel.

A második szakaszban az ország képessége és termelékenysége növekedni kezd, egyre több közvetlen külföldi beruházást vonz, a lokációspecifikus előny kiépítése kulcsfontosságú, de a tőke továbbra is az alacsony szintǔ, elsősorban a fogyasztói termelési iparágakba, az infrastruktúrába, az exportorientált iparágakba és az alacsonyan képzett munkaerőt igénylő ágazatokba áramlik. Az ország aktív FDI-ösztönző programot alkalmaz (exporttámogatás, infrastrukturális és kommunikációs hálózati fejlesztések). A kifelé irányuló beruházások azonban továbbra is csekély mértékúek, bár megjelenik a hazai vállalatok ún. tulajdonspecifikus előnye, de az még nem elég jelentős az OFDIpozíciók eléréséhez. Ezek a vállalatok jellemzően a szomszédos országokban fektetnek be, piackeresés céljából (Dunning és Narula, 2003, 2-4. o.). Ebben a szakaszban a vállalatok a kormány által indított hatékony FDI-ösztönző programok esetén képesek magasabb hozzáadott értékú, technológiaintenzívebb termékeket elóállítani, s ezzel is növelni a külső beruházások lehetőségét. (Ahn és Ngoc, 2016, 5. o.).

A harmadik szakaszban a belföldi bérek és az átlagos jövedelem szintje növekszik, csökken az alacsony költségú munkaerő iránti igény. Az iparosodás és a specializáció jelentősen bővül, javul a hazai piac versenyképessége. A kifelé irányuló közvetlen külföldi tőkebefektetések fokozatosan növekedni kezdenek, megjelennek a hatékonyság- és stratégiaielőny-kereső beruházások. Azonban a nettó külföldi befektetési mérleg még mindig negatív. A hazai vállalatok esetében egyre kisebb a tulajdonspecifikus előnyök jelentősége, mivel a vállalkozások konkrét versenyelőnyöket fejlesztenek ki új immateriális javak (például technológiai innováció, marketing stb.) és exkluzív eszközök (például márka, védjegy és szellemi tulajdon, szerzői jog) létrehozása érdekében. Ezek lehetővé teszik számukra a versenyben való sikeres részvételt. E vállalkozások kevésbé függenek a kormányzati politikától, de szükségük van az onnan érkező ösztönzőkre. Egyesek transznacionális vállalatokká válnak, és tengerentúli társulásokat hoznak létre. Ebben a szakaszban a munkaerő-intenzív termékek helyett egyre inkább tudás- és technológiaintenzív termékek gyártására szakosodnak. A kormányoknak aktívnak kell lenniük az olyan politikák terén, amelyek elősegítik a hatalmas előnyökkel rendelkező iparágakba történő beruházásokat, ösztönzik az ún. tovagyúrúző (spillover) hatásokat, növelik az oktatásra és képzésre fordítandó kiadásokat, orvosolják a piaci tökéletlenségeket, előmozdítják a vállalkozások integrációját és versenyét (Dunning és Narula, 2003, 4-6. o.).

A modell negyedik szakaszában az adott országok a kutatás és fejlesztés szempontjából élen járók közé tartoznak. A kifelé irányuló befektetések meghaladják a befelé irányulókat (a NOIP pozitív), és a hazai vállalatok hatékonyan versenyeznek a külföldi cégekkel. 
Az ötödik szakaszban a nettó külföldi befektetési pozíció nulla körül ingadozik. Az e szakaszban járó államok kapcsán két fő jellemzőt lehet kiemelni: a határokon átnyúló tranzakciók multinacionális társaságokon keresztül történnek, és az ország nemzetközi befektetési pozíciója kiegyensúlyozottabbá válik (Ahn és Ngoc, 2016, 6. o.).

A tanulmányunk során ezt a modellt fogjuk alkalmazni, bár tisztában vagyunk a korlátjaival is. Az egyik, hogy csupán néhány változó szerepel benne (nettó beruházási pozíció, illetve GDP, GDP/fő) és a NOIP nem feltétlenül jól mutatja a strukturális reformok hatásait. Afelől is lehetnek kétségek, hogy a GDP vagy az egy főre jutó GDP mennyire jó gazdasági fejlettségi mutatószám, de mivel az utóbbi nagyrészt elfogadott a nemzetközi szakirodalomban (lásd Todaro és Smith, 2015; Szentes, 2011), így azt vesszük alapul. A másik, hogy John Dunning eredetileg az áramlási FDI adatok kapcsán használta a modellt, amely a statisztikai adatok jellegéből (fluktuáció, statisztikai hibák) adódóan téves eredményekre vezethetnek. Emiatt a befelé és a kifelé irányuló FDI (inward FDI [IFDI], outward FDI [OFDI]) esetében sok szerzőhöz hasonlóan mi is stock, azaz állományi adatokat veszünk figyelembe az elemzés során. Úgy véljük, mindezek ellenére ez a modell megfelelő a magyar múködő tőkekivitel vizsgálatára, hiszen képes megmutatni, hogy Magyarország mely szakaszban jár, és jól jelzi, hogy merre kellene továbbhaladnia.

\section{Az állami támogatások szerepe}

Az OFDI hatásainak a szakirodalma sokrétú. Több empirikus tanulmány (többek között Herzer, 2010; Waqar és Helian, 2017; Zhang, 2001) is hangsúlyozza az OFDI-nek a küldő állam gazdasági növekedésére gyakorolt hosszú távú pozitív hatását. Az OECD (2006) több országtanulmányon keresztül bizonyította ugyanezt a hazai foglalkoztatás, az export és a technológiai kapacitások kapcsán. A pozitív hatások kihasználása, illetve a hazai befektetők gazdasági, politikai, valamint nem kereskedelmi kockázatoktól való védelme érdekében felmerül a kifelé irányuló FDI, az ún. „kifektetések” állami támogatása. Ennek formája sokféle lehet: közvetlen állami támogatások, kedvezményes befektetési hitelnyújtás, garancia nyújtása, különböző képzéseken keresztüli információés tapasztalatátadás stb. Ezek egyfajta csoportosítását az 1. táblázat foglalja össze.

A közvetlen pénzügyi támogatások egyes formáinak közös jellemzője, hogy csökkentik a beruházási projektek gazdasági kockázatát, és ezáltal vonzóbbá teszik azokat a rizikó miatt vonakodó cégek számára. A befektetésbiztosítás és a garancia célja, hogy megvédje a kifektető vállalatokat a fogadó ország politikai és más, nem gazdasági jellegú kockázataitól, amelyekre a hagyományos biztosítások nem terjednek ki. A fiskális ösztönzők közé különböző adókedvezmények tartoznak. A közvetett pénzügyi eszközök többnyire általános intézkedések, amelyek a vállalatok külpiacra lépésének egyéb formáit célozzák, vagy pedig általánosságban hatnak a hazai vállalatok nemzetközi versenyképességére, termelékenységére és teljesítményére. A közvetlen nem pénzügyi 


\section{Külügyi Szemle}

eszközök közül a befektetési lehetőségekre vonatkozó információk megosztása elsősorban távoli célország esetében, illetve a kisebb vagy kevésbé tapasztalt vállalatok számára jelent komoly támogatást. A befektetési egyezmények a befektetóvédelem és a sztenderdek átvétele révén teremt vonzóbb környezetet az OFDI-ben érdekelt cégeknek. A közvetett nem pénzügyi eszközök közül a technológiai támogatás a know-how cseréjén túl a fogadó ország szabályozási környezetének a fejlesztését is szolgálja. A képzési és tanácsadási szolgáltatás a külföldi terjeszkedéshez szükséges tudás megszerzését segíti elő, míg a gyakornoki programok támogatása a munkaerô képességfejlesztését (Gorynia et al., 2015, 241-245. o.).

1. táblázat ${ }^{2}$

A kiáramló FDI-t támogató állami intézkedések csoportosítása

\begin{tabular}{|c|c|c|}
\hline & Közvetlen eszközök & Közvetett eszközök \\
\hline $\begin{array}{l}\text { Pénzügyi } \\
\text { eszközök }\end{array}$ & $\begin{array}{l}\text { - Közvetlen pénzügyi támogatások } \\
\text { - } \quad \text { kedvezményes hitel a } \\
\text { beruházáshoz } \\
\text { - } \quad \text { hitel és hitelgarancia } \\
\text { - } \quad \text { megvalósíthatósági } \\
\text { tanulmányhoz és } \\
\text { projektfejlesztéshez nyújtott } \\
\text { támogatás } \\
\text { - hozzáiárulás külföldön alapított } \\
\text { - cég saját tőkéjéhez } \\
\text { - befektetésbiztosítás és garancia } \\
\text { fiskális ösztönzők }\end{array}$ & 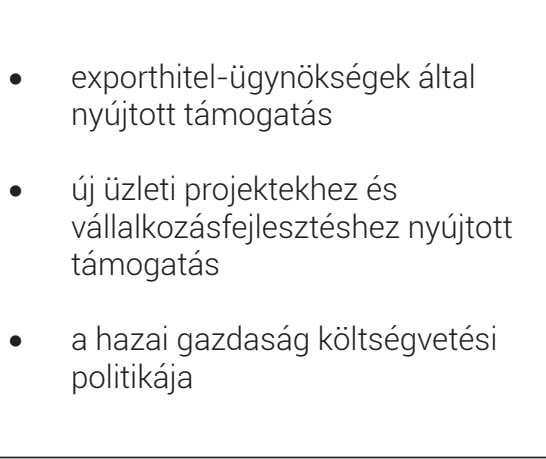 \\
\hline $\begin{array}{l}\text { Nem } \\
\text { pénzügyi } \\
\text { eszközök }\end{array}$ & $\begin{array}{l}\text { - információnyújtás és } \\
\text { kapcsolatfejlesztés } \\
\text { - támogatás nemzetközi } \\
\text { befektetési egyezmények révén }\end{array}$ & 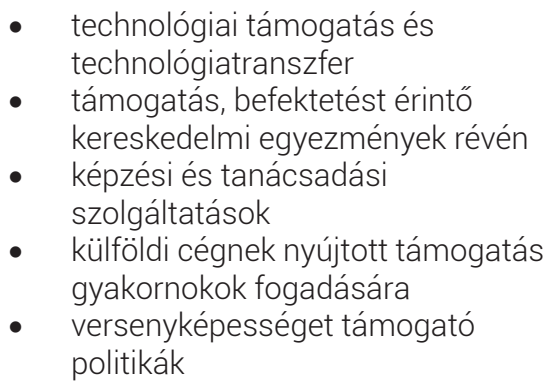 \\
\hline
\end{tabular}

Az 1. táblázat és a hozzá tartozó felsorolás a kiáramló FDI-t támogató állami intézkedések tág értelmezését mutatja; a legtöbb fejlett és fejlődő ország alkalmazza közülük valamelyiket. Gorynia et al. (2015) és Dunning és Narula (2003) elmélete alapján is indokolt az OFDI állami támogatása és lehetôség szerint minél szélesebb körú alkalmazása, ami elsősorban nem közvetlen támogatásokat jelent a multinacionális vállalatok számára, hanem a hazai vállalkozások versenyképességét és nemzetköziesedését segíti elő, kedvező gazdasági helyzetet biztosítva.

2 Forrás: Gorynia et al., 2015, 240. o. 


\section{A magyar OFDI a statisztikák tükrében}

A jelen fejezet célja annak bemutatása, hogy John Dunning IDP-modellje alapján hol tart hazánk a tókekihelyezés folyamatában, azaz reális-e, hogy Magyarország a közeljövőben nettó tőkekihelyező állam lehet.

Magyarország nettó tőkekihelyezó pozíciója

Magyarországon az FDI-statisztikákat a Magyar Nemzeti Bank számolja és teszi közzé. Tanulmányunkban a legújabb, a BPM6 (Balance of Payment Manual 6. verzió) szerinti FDI-adatokat vettük alapul, és figyelmen kívül hagytuk a speciális célú vállalatokkal számoltakat. Az adatok az 1995-ben indult statisztikákban euróban és forintban érhetők el, mi itt, az egy főre jutó GDP-vel történő összehasonlíthatóság érdekében euróban tüntetjük fel az éves értékeket.

\section{2. ábra ${ }^{3}$}

A Magyarországon megvalósuló közvetlen külföldi beruházások és a magyar közvetlentőke-befektetések külföldön 1995 és 2018 között (millió euróban)

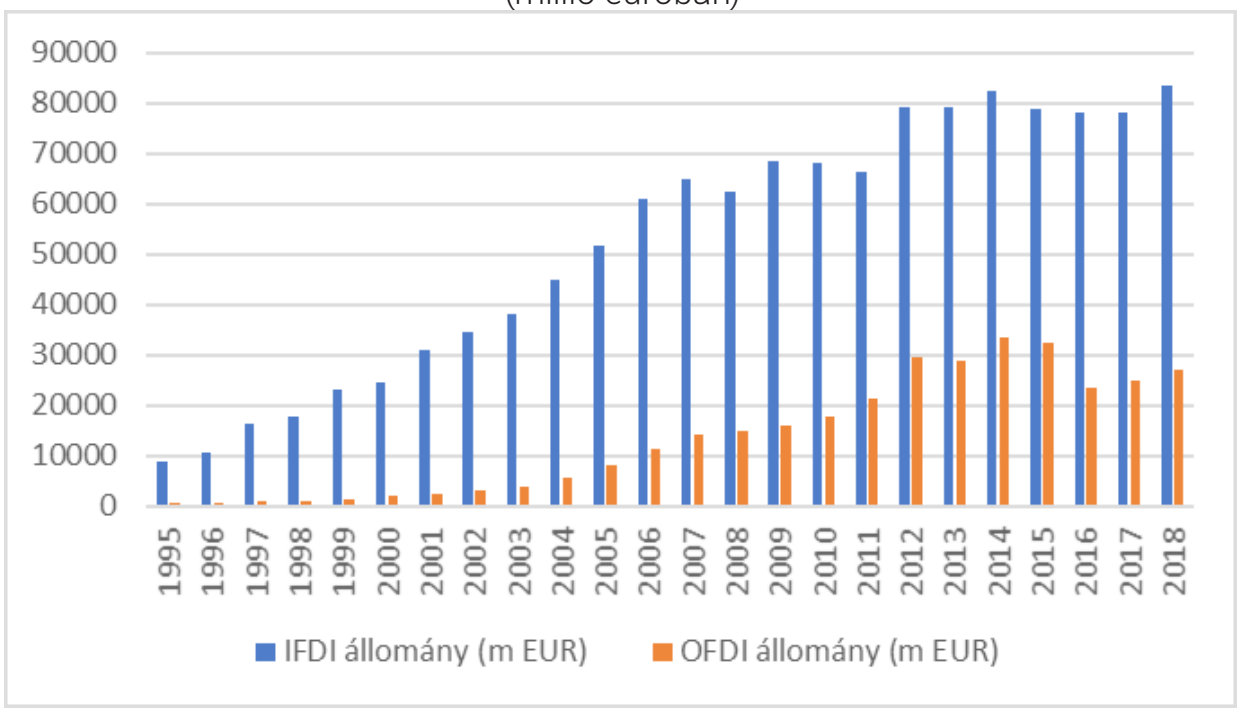

Magyarországon a közvetlen külföldi beruházások állománya 2018-ban 83.699 millió eurót (26.910.312,7 millió forint) tett ki (lásd 2. ábra), ami a magyar GDP több mint 60 százalékának felel meg, míg a külföldi magyar FDI-állomány csupán 26.974 millió euró (8.672.650,44 millió forint) volt (MNB, 2020).

3 Forrás: MNB (2020) adatai alapján. 


\section{Külügyi Szemle}

A 2. ábráról leolvasható, hogy bár a külföldi magyar közvetlentőke-befektetések állományi értéke növekszik, a befelé irányuló FDI továbbra is jóval jelentősebb. Már ebből is kitűnik, hogy Magyarország az IDP-modell második-harmadik szakaszában jár. A nettó tőkekihelyezési pozíció és az egy főre jutó GDP kapcsolatát a 3. ábra szemlélteti.

\section{3. ábra ${ }^{4}$}

Magyarország nettó tôkekihelyezési pozíciója és egy főre jutó GDP-je 1995 és 2018 között

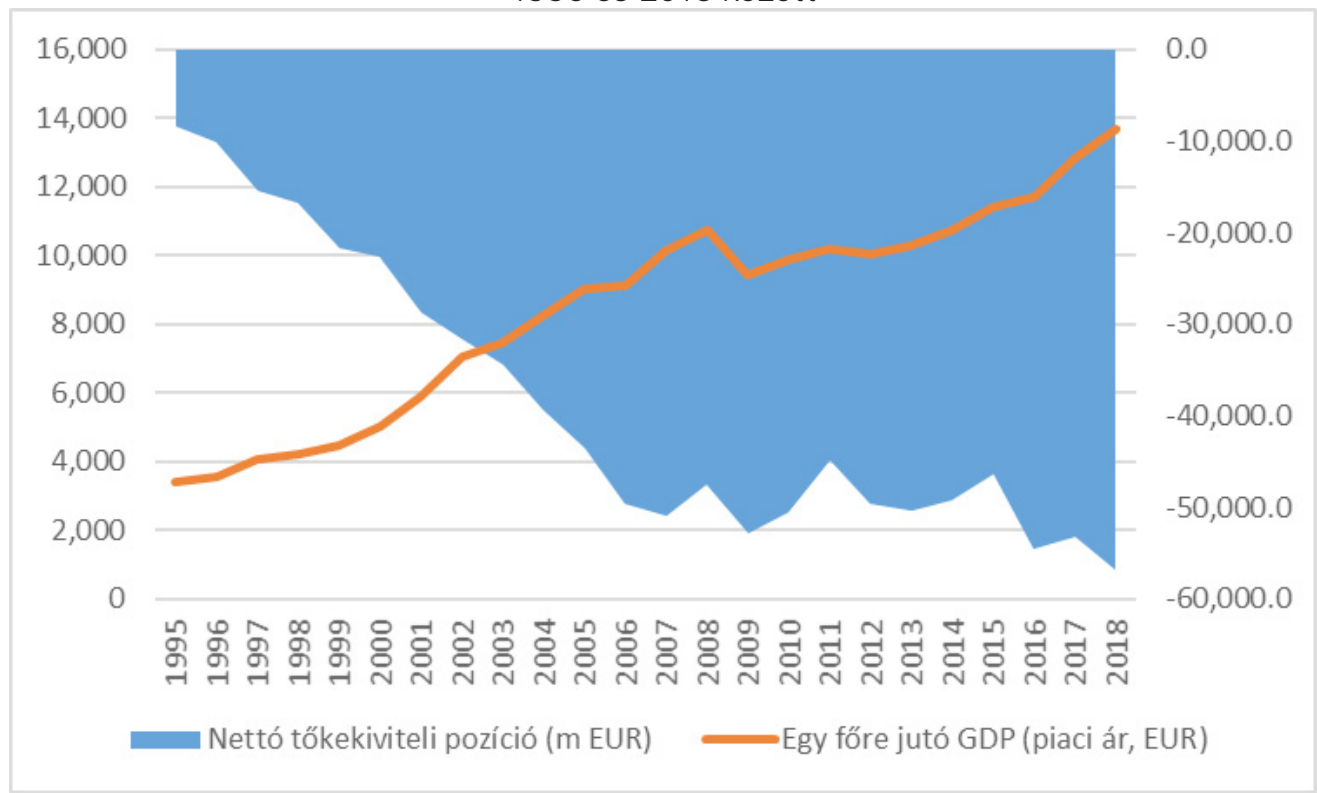

Megjegyzés: A bal oldali skála az egy főre jutó GDP-t, a jobb oldali a nettó tőkekiviteli pozíciót mutatja.

Látható, hogy Magyarországon az egy före jutó GDP folyamatosan növekszik, törést a vizsgált időszakban csak a 2008-2009-es gazdasági válság okozott. A nettó tőkekiviteli pozíció alakulásából pedig az olvasható le, hogy hazánk épp akkoriban lépett be az IDP 3. szakaszába, azonban 2016-tól inkább a modell 2. szakaszára jellemző NOIPpozíciót figyelhetünk meg. Ez azonban nem jelenti azt, hogy Magyarország visszalépett volna, hiszen ez leginkább annak a következménye, hogy bár a magyar vállalatokhoz köthető tőkekihelyezések tovább bővülnek, az ország mégis több FDI-t tud idevonzani. Hazánk lokációspecifikus, illetve a vállalatok tulajdonspecifikus előnyei sem változtak meg jelentős mértékben. Ez a helyzet egybevág a szakirodalom által leírtakkal (lásd többek között: Boudier-Bensebaa, 2008, 38. o.; Sass, 2016b, 117. o.).

4 Forrás: Az MNB (2020) és az Eurostat (2020) adataira épülő saját számítás alapján. 
Ezt az eredményt alátámasztja a magyarországi OFDI regionális és ágazati megoszlása is (továbbá a következő fejezetben ismertetendő esettanulmányok).

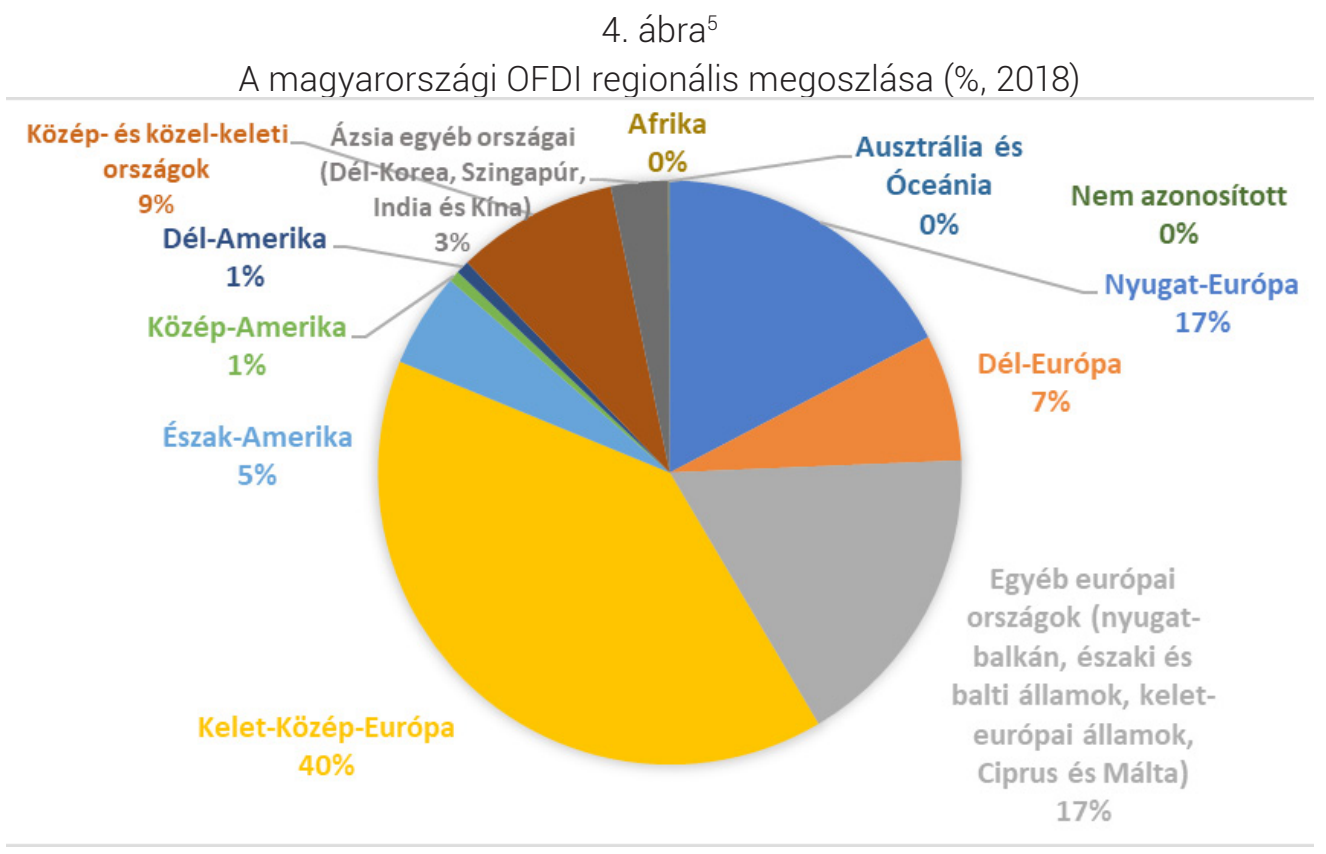

A 4. ábra jól mutatja, hogy bár a magyar vállalkozások kelet-közép-európai beruházásainak az aránya jelentős, nem csupán a régiós projektek a jellemzőek. Mint az szintén megfigyelhető, az Európán kívüli befektetések is számottevőek, s közülük kiemelendő Észak-Amerika (elsősorban az Egyesült Államok), a Közel-Kelet (Izrael), sőt egyre több beruházás jelenik meg ázsiai országokban is (Dél-Korea, Szingapúr, Kína és India). 2010-től egyértelmúen látszik az a tendencia, hogy a magyar FDI-kihelyezések diverzifikálódnak: egyre több Európán kívüli, sőt tengerentúli országban jelenik meg a magyar tôke (MNB, 2020 adatai alapján).

A magyar OFDI ágazati megoszlása (5. ábra) is abban erősít meg bennünket, hogy hazánk az IDP-modell 3. szakaszában jár: egyrészt mivel ágazati szempontból diverzifikáltnak tekinthetőek a kifektetések, másrészt pedig megjelennek a hagyományos, munkaintenzív iparágak mellett a tőkeintenzívekben - az információ és kommunikációban, illetve a szakmai, tudományos, múszaki tevékenységekben - történő kifektetések is. Mindezek ellenére hazánk távol áll attól, hogy nettó tőkekihelyező országgá váljon.

5 Forrás: Az MNB (2020) statisztikái alapján. 


\section{Külügyi Szemle}

\section{5. ábra ${ }^{6}$}

A magyarországi OFDI ágazati megoszlása $(\%, 2018)$

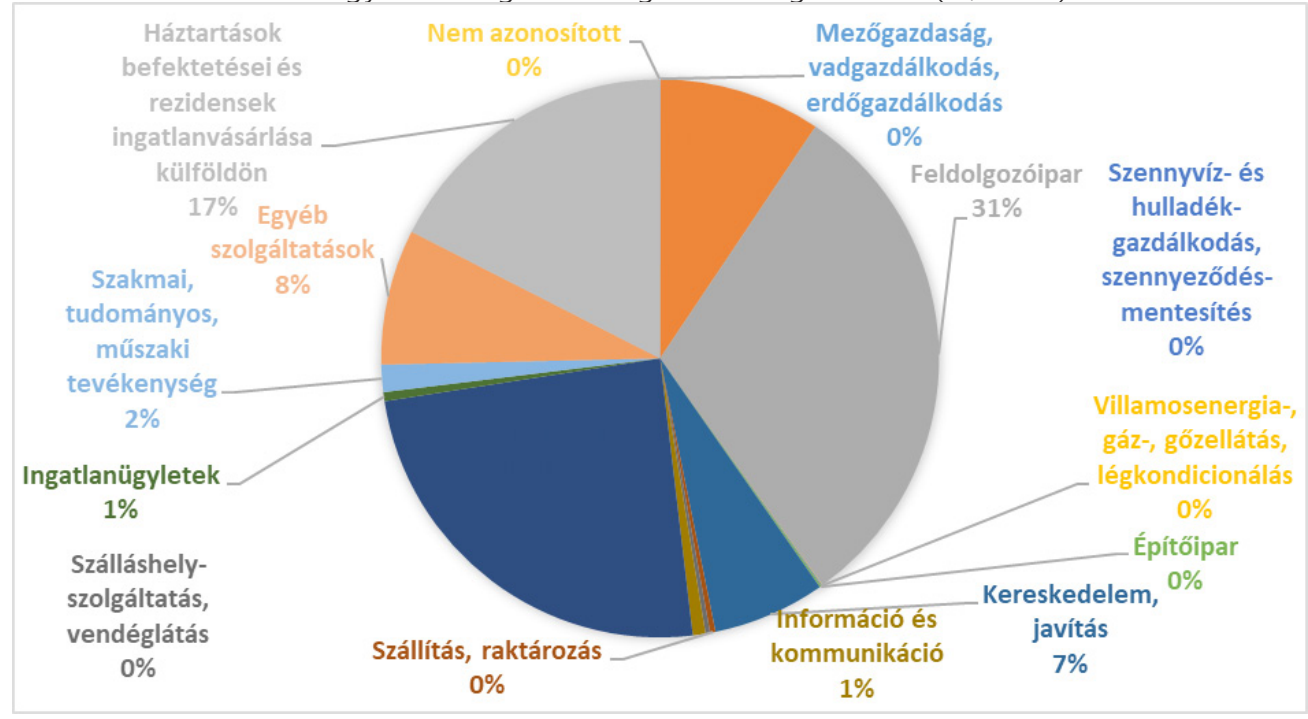

\section{Magyar cégek közvetlen tőkeberuházásai külföldön: esettanulmányok}

Ahogyan korábban arról szó volt, a magyar OFDI sajátosságainak a feltérképezését részben néhány vállalat képviselőivel készített interjúk, részben pedig az egyes beruházásokról egyéb forrásokból elérhető információk alapján végeztük el. A vizsgálatba a Mol-csoportot, a Richter Gedeon Nyrt.-t, az Agrofeed Kft.-t, a Master Good Kft.-t, illetve a Tisza Cipő Csoportot vontuk be.

\section{A külföldön végrehajtott beruházás a vállalati stratégia tükrében}

A Mol-csoport az 1990-es évek végén, illetve a 2000-es évek elején tette meg az első kísérleteket a nemzetközi terjeszkedés irányába. A célpont Észak-Afrika és a Közel-Kelet volt; a vállalat külföldi beruházásaiban egyszerre játszott szerepet az erőforráskeresés (szénhidrogén-lelőhelyek feltárása és kitermelése), valamint a hatékonyságkeresés. A 2010-es évek elejétől a Mol terjeszkedésének az új iránya Nagy-Britannia és Norvégia lett. Az előbbi esetében egy fejlesztési fázisba léptek be 2014-ben, az utóbbiban pedig egy évvel később kutatási portfóliót vásároltak. Több norvég szénhidrogénmező esetében a Mol az operátor cég, s ennek eléréséhez magas belépési kritériumoknak kellett megfelelni, ezért az országban akvizíció révén jelent meg a vállalat. A Mol-csoport

6 Forrás: Az MNB (2020) statisztikái alapján.

7 A Mol-csoport képviselőivel 2019. augusztus 14-én készített interjú alapján. 
esetében ezeknél a beruházásoknál is az erőforrásokhoz való hozzáférésről beszélhetünk az elsődleges motivációként, ugyanakkor megjelenik a stratégiai előnykeresés - egy új piaci szegmensbe (tengeri szénhidrogén-lelőhely és operátori tevékenység) történő belépés - szintje is.

A Richter Gedeon gyógyszergyár 2004-ben döntött úgy, hogy termelőegységet hoz létre Indiában. A döntés fő oka az volt, hogy a vállalat magyarországi telephelyeken lévő gyógyszerhatóanyag-gyártó kapacitása már nem volt elégséges a jövőbeni igények kielégítésére. A hazai termelőegységek bővítésének alternatívájaként merült fel, hogy a cég vegyesvállalat formájában új gyáregységet létesítsen Kínában vagy Indiában. A két projektforgatókönyv költségeinek elemzése után a Richter Gedeon a vegyesvállalat létrehozása mellett döntött, vagyis a cég alapvetően hatékonyságnövelési motivációval kezdett bele az FDI-projektbe. Már annak az implementációs fázisa is igazolta a költségcsökkentési várakozásokat: becslésük szerint a kivitelezés 80 százalékkal került kevesebbe, mint ha Magyarországon hozták volna létre az üzemet. A Mumbaitól 160 kilométerre található Vapiban múködő üzemben a próbagyártás 2006-ban indult meg, a gyáregységben ma 15 különböző hatóanyagot és 80 intermediert gyártanak.

Más a helyzet a takarmányiparban meghatározó szereplőnek számító Agrofeed Kft. esetében. A győri cég 2016. októberben avatta fel az új takarmánypremix-üzemét az oroszországi Jasznogorszkban. A 100 százalékban magyar önerőből megvalósított, 3 milliárd forint értékű zöldmezős beruházás révén a premixgyártó vállalat 8-10-ről 15 százalékra növeli a részesedését az orosz piacon, amelyen már másfél évtizede van jelen. A beruházást alapvetően piackeresési motivációkkal indították el, és a vállalat vezetőinek elmondása szerint az üzem létrehozására azért volt szükség, mert a hazainál tízszer nagyobb orosz piac igényeit a Magyarországról történő szállítással már nem lehetett kielégíteni. A nyugat-európai versenytársak szintén üzemeket hoznak létre Oroszországban, amelyekkel a cégnek lépést kell tartania (MTI, 2016).

A Master Good Kft. FDI-projektje esetében hasonló mozgatórugókról beszélhetünk. A legnagyobb magyar csirkefeldolgozó vállalat 2019 októberében nyitotta meg az első külföldi üzemét. A gyáregység Vietnamban található, az annak északi részén, a Hanoi mellett fekvő Thanh Hoa tartományban. A bejelentés szerint 12 millió eurót költöttek a beruházásra, és eleinte évi 20 millió csirkét fognak feldolgozni, s ezt a mennyiséget később 40 millióra emelhetik. (Sándor, 2019.) A délkelet-ázsiai ország mellett szólt, hogy a közel százmilliós lakosság sokkal kezelhetőbb méretű piacot jelent egy magyar cég számára, mint Kína, ráadásul a népessége és a gazdasága is nő, a középosztálya pedig szélesedik, s egyre nagyobb igény mutatkozik a csirkehúsra. Vietnam emellett tagja az ASEAN-nak, így onnan kiindulva a Fülöp-szigetekkel, Thaifölddel, Malajziával, Indonéziával együtt egy több száz milliós, gyors ütemben bővülő piacra léphet be a vállalat (Concorde MB Partners, 2019).

8 A Richter Gedeon Nyrt. képviselőjével 2019. május 9-én készített interjú alapján. 


\section{Külügyi Szemle}

A Tisza Cipő Csoport ${ }^{9}$ szerbiai FDI-beruházása bizonyos szempontból kakukktojásnak számít a többi vizsgált vállalati példa között. A Tisza Cipő Zrt. 2007-ben döntött úgy, hogy a munkaerő-gazdálkodást külön vállalatba helyezi ki. Az új cég elsősorban a Tisza Cipő számára kölcsönzött munkaerőt, a pénzügyi válság következtében azonban általánosságban is megnőtt az igény erre a szolgáltatásra. A cég ezt követően multinacionális vállalatoknak is kölcsönzött már munkaerőt, ami egyrészt pluszbevételt eredményezett, másrészt erősítette a vállalat partnerképességét.

2013-ra a Tisza Cipónek olyan munkaerőbázisa alakult ki, hogy gyorsan, nagy létszámban tudott munkavállalókat közvetíteni bárhova a régióban. A kikölcsönzött munkaerő a különböző vállalatoknál fokozatosan beletanult az autóalkatrész-gyártásba, ezért a Tisza Cipő Csoport alkatrészek bérgyártásával is elkezdett foglalkozni. A szerbiai partnerrel történt megállapodást követően az alkatrészgyártást 2014-ben indította be a Tisza Automotive. A cégcsoport tehát egy fokozatosan kifejlődő belső munkaerőkompetenciára építve lépett be egy új piaci szegmensbe a beruházás révén.

\section{A beruházási helyszín kiválasztásának szempontjai és az implementáció}

A Mol-csoport esetében a kockázatkezelés a vállalat külföldi befektetéseinek az egyik legfontosabb eleme, mivel számos kockázatosnak minősülő országban található olyan szénhidrogénvagyon, amely érdekes a cég számára. Egy új piacra történő belépés előtt jelentős politikai és gazdasági kockázatelemzés zajlik a vállalaton belül. Ezt követi a geológiai veszélyek felmérése. Szintén kulcsfontosságú a helyi kormánnyal, vezetőkkel való jó kapcsolat kiépítése.

Egy új országban megvalósítandó beruházás esetén kiemelt szerepe van az információszerzésnek. A fejlődő országokról azonban csupán korlátozott mennyiségú ismeret áll rendelkezésre, így a bővebb tájékoztatást a cég részben a helyi partnerétől tudja beszerezni. Egyúttal a belső szakértői csapat is felméri a kockázatokat, illetve külső szakértők, nemzetközi tanácsadó cégek, erre specializálódott vállalatok szolgáltatásait is igénybe veszik.

A Mol projektjei kivitelezésénél általában egy nemzetközi cég a fővállalkozó, amely helyi partnerekkel is dolgoztat. A Mol Pakisztánban az ország negyedik legnagyobb gázmezőjét üzemelteti, az ottani vállalata 400-500 főt foglalkoztat, akiknek a zöme - akárcsak a menedzsment többsége - helyi alkalmazott, így jobban tudnak alkalmazkodni a sajátos körülményekhez. Ugyanakkor a cég általában törekszik arra, hogy a pénzügyi igazgató ne helybéli legyen.

A vállalati esettanulmányokból kitúnik, hogy a megfelelő helyi partner megléte a legtöbb magyar OFDI-projektben központi szerepet játszik. A Richter esetében India mellett szólt, hogy a cégnek már korábban létező kapcsolata volt a Mumbaiban múködő

9 A Tisza Cipő Csoport képviselőjével 2019. március 18-án készített interjú alapján. 
Themis Medicare Ltd. vállalattal. Emellett Kínával szemben a helyiek magasabb szintú angol nyelvtudása, illetve a demokratikus politikai rendszer miatt esett a választás Indiára. Az indiai cég egy megfelelő telekkel rendelkezett egy ipari parkban, s azt felajánlotta az új vegyesvállalat számára. A kivitelezés 18 hónapig tartott - Magyarországon ennél jóval hosszabb időt vettek volna igénybe a munkálatok. Az engedélyezési eljárások és az építkezés figyelemre méltó gyorsasága annak köszönhető, hogy a Richter egy tapasztalt helyi partnerrel múködött együtt - e tényezőt a cég kulcsfontosságúnak ítéli az indiai tevékenységének sikere szempontjából.

A Master Good a kezdetektől fogva partnerségben gondolkodott: a megfelelő üzlettárs megtalálásának reményében vizsgálták korábban Oroszországot, Közép-Ázsiát és Laoszt is. A vietnami első próbálkozása sikertelen maradt, éppen az együttmúködésre államilag kijelölt kolhoz alkalmatlansága miatt. Végül egy fejlesztésen gondolkodó vietnami családi vállalat talált rá a kisvárdai cégre. A vietnamiak elsősorban európai technológiát kerestek, így a Master Good tervezte meg a termelési eszközöket, támogatta az eszközök beszerzését, felügyelte a projekt végrehajtását, betanította a termelésirányító munkásokat. 2017 elején merült fel, hogy a két cég vegyesvállalatot alapítson. Elsőként arról volt szó, hogy csak a feldolgozóipari beruházást fogják együtt megvalósítani. Ez gyakorlatilag megtörtént az üzem 2019. októberi megnyitásával. A tervek szerint a jövőben a vegyesvállalatra egy teljes vertikális integráció fog épülni, a termelési volumen a hazai ötöde lesz, de arra is van esély, hogy viszonylag rövid idő alatt akár az itteni üzem méreteit is elérheti (Concorde MB Partners, 2019).

A Tisza Automotive választása azért esett Szerbián belül Zentára, mert egyrészt nem volt konkurense a városban, másrészt talált olyan gyárépületet, amelyet megvásárolhatott. A Tisza Cipő Csoport több évtizedes gyártási tapasztalattal rendelkezett, ami sokat segített az autóalkatrész-gyártás megkezdésében. A technológiát franchise-ban kapták, az iparágat jellemző szigorú szabványok alkalmazására a partnereik tanították meg őket. Emellett a kulcsfontosságú pozíciókba olyan szakembereket kerestek, akik dolgoztak már kábelkorbácsgyártó üzemben.

A szerbiai gyártás mellett szólt, hogy az ottani bérek jelentősen alacsonyabbak voltak a magyarországiaknál, illetve a partnerük is olyan beszállítót keresett, amely az itteninél alacsonyabb költségek mellett képes termelni. Nagyon sokat jelentett az is, hogy a cégnek volt helyismerete és kialakult kapcsolatrendszere. Szintén előnynek számított, hogy a gyár magyarlakta területen múködött, ami megkönnyítette a kommunikációt. A cég példája is azt mutatja, hogy a helyismeret és a kapcsolatrendszer révén a költségszint jelentősen csökkenthetó. A sikeres zentai múködésre építve a Tisza Automotive 2017ben újabb üzemcsarnokot vásárolt Óbecsén; az ottani gyáregységet 500 fős létszámra tervezték. 2019 júniusában pedig a cég a harmadik szerbiai üzemét is megnyitotta Nagykikindán, a beruházással 320 új munkahelyet teremtve (Tímár, 2019). 


\section{Külügyi Szemle}

Tapasztalatok és kihívások

A Mol tapasztalatai szintén azt támasztják alá, hogy elengedhetetlen az erős, megbízható helyi partner, s a szerepe annál fontosabb, minél távolabbi országba szeretne belépni egy magyar cég. Lényeges a hosszú távra - akár 5-10 éves távlatra - tervezés, és a cégnek elegendő vagyonnal kell rendelkeznie ahhoz, hogy finanszírozni tudja az eleinte várható veszteséget. A sikerhez elsősorban a beruházási döntést megelőző alapos piacelemzésre van szükség.

A Richter esetében a magyar-indiai vegyesvállalat előtt álló egyik legnagyobb kihívás a "kékgalléros" munkaerő rendkívül nagy fluktuációja. A cég várakozásai szerint e téren nem várható érdemi változás, így a kulcsfontosságú alkalmazottak és a menedzserek hosszú távú megtartására törekednek. Emellett a szigorodó környezetvédelmi előírásoknak történő megfelelés is egyre nagyobb erőfeszítéseket igényel.

A Master Good szerint a földrajzi távolság, az időeltolódás, a kommunikáció nehézségei és a kulturális különbségek egyaránt nehezítik a vegyesvállalat múködtetését. A nehézségeket a partnerség létrehozásában közremúködő ügyvezető igazgató személye, illetve a gyakori kiutazások révén igyekeznek kezelni (Concorde MB Partners, 2019).

A Tisza Automotive esetében a kezdeti időszak legnagyobb kihívása az volt, hogy hogyan lehet a helyieket visszaszoktatni a rendszeres munkához - a vállalati kultúra meghonosítására több millió eurót költött a cég. A hatékonyságvesztés elkerülése érdekében meg kellett tanítani az embereket a munkaidő és egyéb korlátok pontos betartására, a munkavédelmi eszközök használatára. Az átlagos gyárhatékonyság kezdetben mindössze 50-60 százalékos volt, amit 2018-ra 95 százalékra sikerült feltornázni. A kezdeti időszakban további kihívást jelentett, hogy a szerbiai beszállítók nagyon rossz minőségben dolgoztak.

\section{Az állami támogatás hazai gyakorlata}

\section{Az EXIM szerepe az állami támogatások terén ${ }^{70}$}

Az EXIM-nél 2019 során kezdődött el a külföldön megvalósuló magyar vállalati tôkebefektetések támogatására irányuló termékfejlesztési munka, ám a koronavírus-járvány lelassította a folyamatot. Ezzel együtt a banknak jelenleg is van elérhető kifektetési hitelkonstrukciója, bár az nem államilag támogatott hitel, így a kondíciói olyanok, mint a kereskedelmi banki hiteleké. Az EXIM e konstrukcióból nem rendelkezik számottevő portfólióval, s a szervezetnél vizsgálják az állami támogatású hitelek nyújtásának a lehetőségét, ám ez egyelőre csak a jövőre vonatkozó terv.

10 Az EXIM képviselőivel 2020. május 26-án készített interjú alapján. 
Az OFDI-t támogató állami intézkedések közül (1. táblázat) az EXIM elsősorban indirekt eszközökkel támogatja a kifektetésben érdekelt hazai cégeket. Ennek keretében a hazai vállalkozásnak nyújtanak finanszírozást, amelynek az ily módon megerősödött magyarországi pénzügyi pozíciója teszi lehetővé a külföldi tőkeberuházását. Az ilyen cégek döntő többsége exportőr, és a külföldi beruházást jellemzően önerőből oldják meg. Az EXIM pedig a cégek forgóeszközigényéhez nyújt alacsony, fix kamatozású, hosszú lejáratú hiteleket, s azok által erősíti a vállalat hazai pénzügyi helyzetét. Ám az EXIM-nek több olyan biztosítási konstrukciója is van, amely a külföldi leányvállalatra is kiterjed. A kkv-k esetében a projekt finanszírozását jellemzően a helyi kereskedelmi bank végzi, az EXIM pedig garanciavállalással tudja támogatni a beruházást. Nagyvállalatok számára gyakoribb a direkt támogatás. A bank tapasztalatai megerősítik a vállalati esettanulmányok egyik legfontosabb megállapítását, miszerint a megfelelő helyi partner megtalálása szinte valamennyi projekt esetében kiemelten fontos.

Az EXIM elvégzett egy felmérést a saját ügyfélkörében, és a megkérdezett 70 hazai cég közül 32 nyilatkozott úgy, hogy rendelkezik külföldi tőkeberuházással, vagy szerepel ilyen jellegú projekt a következő évekre vonatkozó tervei között. Szintén az EXIM felméréséből derült ki, hogy a kifektető hazai cégek kifejezetten sokfélék: az árbevételük 30 millió és 60 milliárd euró között változik, az alkalmazotti létszám a néhány főtől 1600-ig terjed, s a mintában egyaránt szerepeltek kis- és középvállalkozások, illetve nagyvállalatok.

A megkérdezett cégek tapasztalatai szerint a külföldön megvalósított közvetlen tőkeberuházás elsődleges pozitív hozadéka többnyire az export növekedése volt. A problémák között említették a partnerország jogi környezetéről szóló információk hiányát, a megfelelő munkaerő megtalálását, a nyelvi nehézségeket, az eltérő vállalati kultúrát, valamint a finanszírozási akadályokat. A külföldön beruházó vállalatok elsősorban olyan banki termékeket látnának szívesen, amelyek arányos, a befektetés mértékéig terjedő kockázatviselést tesznek lehetővé. Ami a finanszírozást illeti, a cégek többnyire 20-30 százaléknyi önerőben gondolkodnak, ám az 50 százalékos önerő sem számít ritkaságnak.

Az EXIM adatai alapján a magyar kifektetések elsődleges célországa Szlovákia, Szerbia, Románia, Csehország, Ausztria, Oroszország és Németország. A kifektetési stratégia szempontjából a magyar cégek számára kulcsfontosságú a Balkán is. A távolabbi országok iránt szórványosabb az érdeklődés, jellemzően néhány nagyvállalat részéről, a kkv-k főleg a régiónkban kívánnak befektetni.

\section{A Magyar Exportfejlesztési Ügynökség és a Nyugat-Balkán Beruházási Támogatás ${ }^{11}$}

A Külgazdasági és Külügyminisztérium által elindított Nyugat-Balkán Beruházási Támogatás program gyökerei a Magyarország Kormánya és a Szerb Köztársaság Kormánya közötti gazdasági és technikai együttmúködési megállapodásig nyúlnak vissza,

11 A HEPA képviselőjével 2020. június 3-án készített interjú alapján. 
melyet a 40/2018-as kormányrendeletben hirdettek ki. Az egyezmény célja, hogy elősegítse a két ország kooperációját az infrastruktúra-fejlesztés terén, s ennek keretében olyan szerbiai infrastrukturális projekteket terjesztettek elő, amelyekhez a magyar fél technológiát, szakértői hátteret tudott hozzárendelni.

A Nyugat-Balkán Beruházási Támogatás múködtetéséhez kapcsolódó feladatokat a Magyar Exportfejlesztési Ügynökség (HEPA) Nyugat-balkáni Programok Végrehajtásáért Felelős Igazgatósága látja el. A támogatási eszköz célja a magyar cégek régiós jelenlétének és szerepének erősítése a balkáni térségben. A vissza nem térítendő támogatásként odaítélhető forrás kedvezményezettjei magyarországi gazdasági társaságok, ám a támogatást ténylegesen a külföldi leányvállalat vagy a magyar cég többségi tulajdonában levő vegyesvállalat kapja meg, tőkeemelés révén, vagyis az intézkedés az 1. táblázatban bemutatott, az FDI-projektekhez közvetlenül köthető pénzügyi támogatások közé tartozik. A megítélt összeg a Szerb Köztársaság, Montenegró, illetve Bosznia-Hercegovina területén induló beruházásokra fordítható. A rendelkezésre áló keretösszeg 2,85 milliárd forint, a támogatott beruházások maximális időtartama - az előkészítési időszakkal együtt - 36 hónap. A pályázat ágazati megkötést nem tartalmaz.

2020. január 31-ig 30 pályázatot nyújtottak be, összesen 20 milliárd forintot meghaladó támogatási összegre. Az átlagos támogatás 600-700 millió forint körül mozog. Főként termelő beruházások, illetve zöldmezős projektek találhatók a pályázatok között; a támogatást főleg az élelmiszeripar, a mezőgazdasági raktározás, az építőipar, az energetika és a turizmus területéről igényelték, de nyújtottak be rá igényt az IT- és a mérnöki szolgáltatással, illetve az egészségipari csomagolástechnikával kapcsolatos fejlesztésekre is. A pályázatok 80 százaléka szerbiai projektekre vonatkozik. A támogatandók értékelésébe bevonják a három célország nemzeti befektetési ügynökségét is, és csak az általuk is elfogadott beruházási terv kaphat magas pontszámot. Ezáltal arra is lehetőség kínálkozik, hogy a projektek a megvalósítás helyén múködő befektetési ügynökségtôl is támogatásban részesülhessenek.

A Covid-19-járvány a pályázatot abban a tekintetben befolyásolhatja, hogy a nyertes vállalatok egy része esetleg nem lesz képes tartani a kírásban szereplő ütemezést, ezért a kiíró részéről minden bizonnyal rugalmasságra lesz szükség e téren.

\section{Következtetések}

A tanulmány első két fejezetének a megállapításai alapján elmondható, hogy Magyarország 2008-2009 környékén lépett Dunning IDP-modelljének a 3. szakaszába, és annak továbbra is inkább még az elején jár, mivel az elmúlt években az egy före jutó GDP folyamatos növekedése ellenére az OFDI nem nőtt olyan mértékben, mint az IFDI. Az OFDI ágazati diverzifikációja, a hagyományos, munkaintenzív iparágak mellett a tôkeintenzív iparágakban történő kifektetések megjelenése is ezt támasztja 
alá, akárcsak a vállalati esettanulmányokban ismertetett beruházások egyes jellemzői (például a hatékonyság- és stratégiaielőny-keresés, a régiónkon kívüli országokban végrehajtott beruházások).

A vállalati esettanulmányokban szereplő beruházások a stratégiai cél alapján sokszínűek, mind a négy fő mozgatórugóra találni köztük példát. A tapasztalatok szerint a magyar cégek külföldi beruházási helyszínének a kiválasztásakor kiemelkedő jelentősége van az információszerzésnek és a helyismeretnek. Információt a cégek a saját belső elemzési erőforrásaik, tanácsadó cégek vagy a magyar diplomáciai hálózat révén gyújtenek be elsősorban, illetve alkalmanként további állami szereplők tudnak ebben segítséget nyújtani nekik. A megfelelő helyi partner megtalálása többnyire kulcsfontosságú tényező: nem csupán a beruházás megvalósításánál játszik szerepet, de a sikeres múködtetésben is - minél távolabbi a célország, annál fontosabbat. Bizonyos esetekben a helyismeret a múködési költségek csökkentését, s ezáltal a versenyképesség növelését is elősegíti, akár egy szomszédos országban is. A munkaerő megtartása, képzése, a vállalati kultúra meghonosítása, a kommunikáció szinte minden esetben kihívást jelent, ugyanakkor a tapasztalatok szerint ezek a problémák kezelhetók, ha a külföldi múködés kulcspozícióira sikerül megtalálni és megtartani a megfelelő szakembert.

Bár nem tekinthető reprezentatívnak, az EXIM belső felmérése szerint az ügyfélkörükben meglepően nagy azoknak a magyar cégeknek az aránya, amelyek külföldi beruházást fontolgatnak. A Nyugat-Balkán Beruházási Támogatás program iránti nagyfokú érdeklődés szintén ezt támasztja alá. Ugyanakkor ezek az információk sem adnak okot arra, hogy a magyar cégek kifektetési tevékenységének a látványos növekedésére számítsunk a következő években. Ennek több oka is van. Egyrészt az IDP-modell alapján jelenleg hazánk még távol áll attól, hogy kifejezetten tőkekibocsátó állam legyen - ehhez először kiemelkedő K+F-kapacitásokkal rendelkező országgá kell válnia. Másodszor, egy külföldi beruházás vállalkozó szellemet, agilitást és nemzetközi perspektívát is feltételez egy vállalattól, ami sokszor szűk keresztmetszetnek számít a magyar cégek körében. Harmadszor, a külföldre irányuló FDI-projektek elmaradásának strukturális okai is lehetnek. Erre utal egy lengyel exportőrök körében végzett felmérés: a megkérdezettek közel 70 százaléka szerint a vállalata számára szükségtelen, hogy külföldi beruházásban gondolkodjon, 16 százalékuk pedig arról számolt be, hogy cégcsoport tagjaként a vállalkozásnak nincs önálló beruházási stratégiája. A tőkehiányt a válaszadóknak mindössze 7 százaléka jelölte meg az OFDI-projekt elmaradásának okaként (Polish Economic Institute, 2020, 36. o.). Negyedszer pedig a koronavírus-járvány gazdasági következményei is hatással lehetnek a hazai vállalatok külföldi beruházási hajlandóságára. Habár a globális ellátási láncok átrendeződése nem érinti közvetlen módon a legtöbbször regionális léptékben gondolkodó magyar cégeket, egy elhúzódó gazdasági válság minden bizonnyal lassítja a hazai vállalatok nemzetközi üzleti terveinek a megvalósítását. 
Ezzel együtt szükséges, hogy a magyar állam igyekezzen megtalálni azokat az eszközöket, amelyekkel a leghatékonyabban tudja támogatni a hazai cégek OFDI-projektjeit. A tanulmányban bemutatott elméletek szintén arra utalnak, hogy Magyarország a tôkekihelyezővé válásnak azon szakaszában tart, amelyben fontos az állam szerepe. Bár szó van már a közvetlen támogatást jelentő banki termékek kifejlesztéséről, a jelenlegi hazai gyakorlat inkább indirekt eszközöket alkalmaz. A jövőben az állam feladata egyrészről az lesz, hogy gazdaságpolitikai eszközökkel segítse a vállalatokat a márkaépítésben, a termékdifferenciálásban, valamint abban, hogy egyre tudásintenzívebb termékekkel jelenjenek meg a világpiacon. Vagyis a továbblépés egyik kulcsa, hogy az állam mennyiben tud kialakítani és fenntartani egy, a vállalatok versenyképességét és nemzetköziesedését támogató környezetet. A vonatkozó stratégiát nem elsősorban a Mol és Richter kategóriájába tartozó cégekre kell szabni, hanem azokra, amelyeknek esélyük van az említett két national champion nyomdokaiba lépni. Másrészről pedig egyes állami szereplők szolgáltatásai is elősegíthetik a tőkekihelyezővé válás útján történő továbblépést. Az EXIM tapasztalata szerint a külföldön beruházó magyar vállalatoknak egyfajta komplex tanácsadásra lenne szükségük, ami túlmutat a klasszikus banki szolgáltatásokon. Az átfogó vállalati beruházási stratégia kidolgozásához nyújtott segítség, illetve a már megvalósított magyar OFDI-projektekkel kapcsolatos tudásmegosztás megszervezése lehet a jövő útja e tekintetben.

\section{Irodalomjegyzék}

Ahn, Nguyen Thi Kim és Ngoc, Le Hong (2016). Introduction to the Theoretical Framework of Dunning's Investment Development Path. VNU Journal of Science: Education Research, 32(5), 1-11.

Almadi Sejla (2018). Can the V4's Priorities Shape "Europe's Priorities"? The Multiannual Financial Framework 2021-2027. EUROPEUM Institute for European Policy. A letöltés ideje: 2020. május 15. http://www.europeum.org/data/articles/5-sejla.pdf.

Antalóczy Katalin, Éltető Andrea és Sass Magdolna (2014). Outward FDI in Hungary: The Emergence of Hungarian Multinationals. Entrepreneurial Business and Economics Review, 2(3), 47-62.

Balatoni András és Pitz Mónika (2012). A múködőtőke hatása a bruttó nemzeti jövedelemre Magyarországon. Közgazdasági Szemle, 69(1), 1-30.

Bisztray Márta (2016). The Effect of FDI on Local Suppliers: Evidence from Audi in Hungary. IEHAS Discussion Papers MT-DP 2016/22. Budapest: Magyar Tudományos Akadémia.

Boudier-Bensebaa, Fabienne (2008). FDI-Assisted Development in the Light of the Investment Development Path Paradigm: Evidence from Central and Eastern European Countries. Transnational Corporations, 17(1), 37-67.

Concorde MB Partners (2019). Tudás- és tôkeexport Vietnámba. A letöltés ideje: 2020. június 8. https://cmbp.hu/tudas-es-tokeexport-vietnamba/.

Dunning, John H. (1997). Alliance Capitalism and Global Business. London: Routledge. 
Dunning, John H. és Narula, Rajneesh (2003). Foreign Direct Investment and Governments: Catalysts for Economic Restructuring. London: Routledge.

Eurostat (2020). Database. A letöltés ideje: 2020. május 15. https://ec.europa.eu/ eurostat.

Franco, Chiara, Rentocchini, Francesco és Marzetti, Guiseppe Vittucci (2008). Why Do Firms Invest Abroad? An Analysis of the Motives Underlying Foreign Direct Investments. SSRN. A letöltés ideje: 2020. május 30. https://ssrn.com/abstract=1283573.

Gál Zoltán (2019). Az FDI szerepe a gazdasági növekedés és a beruházások területi differenciálódásában Magyarországon. Közgazdasági Szemle, 66(6), 653-686.

Gál Zoltán, Sass Magdolna és Juhász Bálint (2016). A külföldi közvetlentőke-befektetések és a válság hatása a fogadó gazdaságra: a visegrádi országok egyes szolgáltató ágazatainak vizsgálata. MTAK. A letöltés ideje: 2020. május 25. http://real.mtak. hu/39540/1/Sass_es_tsai__A_kulfoldi_kozvetlentoke_befektetesek_es_a_valsag_ hatasa_a_fogado_gazdasagra_u.pdf.

Gorynia, Marian, Nowak, Jan, Trapczyński, Piotr és Wolniak, Radosław (2015). Government Support Measures for Outward FDI: An Emerging Economy's Perspective. Argumenta Oeconomica, 7(34), 229-258.

Herzer, Dierk (2010). Outward FDI and Economic Growth. Journal of Economic Studies, 37(5), 476-494.

Miniszterelnöki Kabinetiroda (2019). Orbán Viktor beszéde a Magyar Kereskedelmi és Iparkamara gazdasági évnyitó rendezvényén. A letöltés ideje: 2020. június 11. http://www.miniszterelnok.hu/orban-viktor-beszede-a-magyar-kereskedelmi-esiparkamara-gazdasagi-evnyito-rendezvenyen-3/.

MNB (2020): BPM6 módszertan szerinti adatok. A letöltés ideje: 2020. június 12. https://www.mnb.hu/statisztika/statisztikai-adatok-informaciok/adatok-idosorok/ viii-fizetesi-merleg-kozvetlen-tokebefektetesek-kulfolddel-szembeni-allomanyok/ kozvetlentoke-befektetesek/bpm6-modszertan-szerinti-adatok.

MTI (2016). Felavatták a magyar Agrofeed takarmánypremix-üzemét Oroszországban. Agronapló. A letöltés ideje: 2020. június 3. https://www.agronaplo.hu/hirek/felavattaka-magyar-agrofeed-takarmanypremix-uzemet-oroszorszagban.

OECD (2006). International Investment Prespectives. Párizs: OECD Publications.

Polish Economic Institute (2020). Outward Foreign Direct Investment by Polish Enterprises - Trends, Prospects. A letöltés ideje: 2020. június 10. http://pie.net.pl/wpcontent/uploads/2018/07/Outward-foreign-direct-investment.pdf.

Sándor Krisztián (2019). Miért megy a baromfıkirály Vietnámba? Forbes. A letöltés ide-

je: 2020. június 3. https://forbes.hu/uzlet/miert-megy-a-baromfikiraly-vietnambamaster-good-beruhazas-vietnam/.

Sass Magdolna (2016a). Közvetlentőke-befektetések a kelet-közép- és kelet-európai EU-tagországok között. Statisztikai Szemle, 94(8-9.), 856-880.

Sass Magdolna (2016b). Latecomers May Be Admitted: Foreign Direct Investment Between the CEE Countries. In Szent-Iványi Balázs (szerk.). Foreign Direct Investment in Central and Eastern Europe, Post-Crisis Perspective. London: Palgrave Macmillan (99-126. o.). 


\section{Külügyi Szemle}

Sass Magdolna és Vlčková, Jana (2020). Just Look Behind the Data! Czech and Hungarian Outward Foreign Direct Investment and Multinationals. Acta Oeconomica, 69(S2), 73-105.

Szentes Tamás (2011). Fejlődásgazdaságtan. Budapest: Akadémiai Kiadó.

Szerb László, Márkus László és Csapi Vivien (2015). Kis- és középvállalatok nemzetközi környezetben - hazai és külföldi tapasztalatok. In Blahó András, Czakó Erzsébet és Poór József (szerk.). Nemzetközi Menedzsment. A letöltés ideje: 2020. május 10. https://mersz.hu/hivatkozas/dj73nm_254\#dj73nm_254.

Tímár Zsolt (2019). Új munkahelyeket biztosít a Tisza Automotive Kft. Nagykikindán. Pannon RTV. A letöltés ideje: 2020. június 4. https://pannonrtv.com/rovatok/ gazdasag/uj-munkahelyeket-biztosit-tisza-automotive-kft-nagykikindan.

Todaro, Michael P. és Smith, Stephen C. (2015). Economic Development. London: Pearson.

UNCTAD (2007). World Investment Report 2007, Transnational Corporations, Extractive Industries and Development. Genf: United Nations.

Waqar, Amil és Helian, Xu (2017). The Long-Run Effect of Inward and Outward Foreign Direct Investment on Economic Growth: Evidence from Developing Countries. Review of Innovation and Competitiveness, 3(2), 5-24.

Zhang, Kevin Honglin. (2001). Does Foreign Direct Investment Promote Economic Growth? Evidence from East Asia and Latin America. Contemporary Economic Policy, 19(2), 175-185. 